\title{
FORMULATION AND EVALUATION OF NOVEL IN SITU GEL OF LAFUTIDINE FOR GASTRORETENTIVE DRUG DELIVERY
}

\author{
SINDHOOR S M, SNEH PRIYA*, AMALA MAXWELL
}

Department of Pharmaceutics, NGSM Institute of Pharmaceutical Sciences, Nitte (Deemed to be University), Deralakatte, Mangalore -575 018, Karnataka, India. Email: snehpriya123@gmail.com

Received: 03 March 2018, Revised and Accepted: 20 April 2018

\section{ABSTRACT}

Objective: The aim of the present study was to formulate and evaluate the novel in situ gel of lafutidine for gastroretentive drug delivery

Methods: A gastroretentive in situ gel of lafutidine was formulated by pH-triggered ionic gelation method using different concentrations of gelling polymer such as sodium alginate, gellan gum, and xanthum gum. Prepared formulations were evaluated for viscosity, density, buoyancy lag time and buoyancy duration, and drug content. In vitro drug release studies of all formulations were also performed. In vivo fluorescence imaging study was conducted for optimized formulation and compared with control.

Results: The concentration of gelling agents and release retardant polymers significantly affected viscosity, floating behavior, and in vitro drug release of the formulations. The $\mathrm{pH}$ and drug content were found in the range of 6.72-7.20 and 88.74-95.33\%, respectively. Floating lag time was $<2$ min; duration of floating was more than $12 \mathrm{~h}$. Minimum and maximum in vitro drug release were found to be for formulation F9 (51.74\%) and F1 (82.76\%), respectively, at the end of $12 \mathrm{~h}$. The drug was released from the all the formulations in a sustained manner. In vivo studies confirmed the gastroretention of the formulation in mice stomach for $8 \mathrm{~h}$. Stability studies indicated that the there was no significant change in the visual appearance, floating behavior, and drug content.

Conclusion: The gastroretentive in situ gel system, prolonged the gastric residence time, thereby targeting site-specific drug release in the upper gastrointestinal tract.

Keywords: Lafutidine, Gastroretentive in situ gel, pH-triggered gelation.

(c) 2018 The Authors. Published by Innovare Academic Sciences Pvt Ltd. This is an open access article under the CC BY license (http://creativecommons. org/licenses/by/4. 0/) DOI: http://dx.doi.org/10.22159/ajpcr.2018.v11i8.25582

\section{INTRODUCTION}

There has been a renewed interest in the academia as well as the industry toward the development of gastroretentive in situ gelling system. This is mainly due to the considerable advantages of the in situ gelling system such as ease of administration and reduced frequency of administration, which help to increase the patient compliance [1]. Gastroretentive in situ gelling system also known as stomach-specific systems have the ability to provide controlled drug delivery within the stomach with enhanced gastroretention. In situ gelling systems are liquid at room temperature but undergo gelation when in contact with body fluids or change in $\mathrm{pH}$ [2]. Since the gel formed from in situ gelling system is lighter than gastric fluids, it floats over the stomach contents or adhere to gastric mucosa due to the presence of bioadhesive nature of polymer and produce gastric retention of dosage form and increase gastric residence time resulting in prolonged drug delivery in the gastrointestinal tract $[3,4]$. The system makes use of polymers that undergo sol-gel phase transition owing to changes in specific physicochemical parameters. Different polymers which are used for the formation of in situ gel include gellan gum, alginic acid, xyloglucan, pectin, chitosan, polycaprolactone, polylactic acid, and poly(lactic-co-glycolide). The principle involved in the in situ gel formation is the pH-induced ionic gelation. The trisodium citrate incorporated into the formulation helps to maintain the formulation in liquid form until it reaches the stomach. Once the formulation reaches the stomach, in the presence of acidic environment $\mathrm{Ca}^{++}$gets released and triggers the gelation of the formulation. The carbon dioxide that is released in the gastric $\mathrm{pH}$ helps to maintain the buoyancy of the in situ gel for an extended period $[5,6]$.

Lafutidine is a novel second-generation histamine $\mathrm{H}_{2}$-receptor antagonist. It is absorbed in the small intestine, reaches gastric cells through the systemic circulation, and then directly and rapidly binds to gastric cell histamine $\mathrm{H}_{2}$ receptors, resulting in immediate inhibition of gastric acid secretion. Lafutidine is used in the treatment of gastric ulcers, duodenal ulcers, and gastric mucosal lesions associated with acute gastritis. Lafutidine has a receptor binding affinity which is 2-80 times higher than other representative $\mathrm{H}_{2}$-receptor antagonists (e.g., famotidine, ranitidine, and cimetidine) [7].

However, lafutidine has a short biological half-life and low bioavailability, therefore, requires frequent dosing. Hence, gastroretentive drug delivery of lafutidine in the form of oral in situ gel will increase the residence time of the drug and also will release the drug for an extended period, thereby can reduce the frequency of dosing and also increase the bioavailability.

\section{MATERIALS AND METHODS}

\section{Materials}

Lafutidine was gifted by Zuventus Healthcare Ltd., xanthum gum, trisodium citrate, calcium carbonate, Tween 80, liquid paraffin, concentrated $\mathrm{HCl}$, and sodium fluorescein were purchased from Loba Chemie, Mumbai, India. Sodium alginate and gellan gum were obtained from Himedia laboratories, Mumbai and Yarrow chem Products, Mumbai, India, respectively. Deionized water was purchased from BN laboratories Mangalore, India.

\section{Methods}

Preparation of the gastroretentive in situ gel

The required quantities of sodium alginate, gellan gum, xanthum gum, trisodium citrate, calcium carbonate, propylparaben, and methylparaben were weighed accurately along with the measured quantities of Tween 
80 and liquid paraffin. Various concentrations of gelling polymer (sodium alginate or gellan gum) were dissolved in deionized water with weighed amount of trisodium citrate on a magnetic stirrer at $70^{\circ} \mathrm{C}$. After the above solution has cooled down to $40^{\circ} \mathrm{C}$ calcium carbonate and release retardant polymer xanthum gum was added. In another beaker, required quantities of Tween 80 and liquid paraffin were added and kept for stirring in a magnetic stirrer. Water was then added drop by drop to form an emulsion followed by the addition of weighed amount of the drug with continuous stirring. The polymeric solution was then added to this drug solution followed by the addition of preservatives, i.e., methyl and propylparaben. Finally, the volume was adjusted with the deionized water, and the resultant solution was stirred well and stored in ambercolored bottles until further use [6]

\section{Drug excipient compatibility studies}

Fourier transform infrared (FTIR) spectroscopy was performed using a Shimadzu FTIR 8300 Spectrophotometer and from 4000 to $400 / \mathrm{cm}$ region, the spectrum was recorded. The drug was dispersed in $\mathrm{KBr}(200-$ $400 \mathrm{mg}$ ) and made into disc form by compressing it with a pressure of 5 tons for $5 \mathrm{~min}$ in a hydraulic press and the spectrum was obtained. The spectra obtained for drug and optimized formulation was compared [8].

\section{Characterization of in situ gel}

Determination of the visual appearance

All the formulations were visually inspected for their appearance, clarity, and consistency.

\section{Measurement of the $\mathrm{pH}$}

The $\mathrm{pH}$ for each of the formulations was measured using a calibrated pen $\mathrm{pH}$ meter. The readings were recorded three times for each of the formulation and the averages of the readings were considered [9].

\section{In vitro gelation study}

$5 \mathrm{ml}$ of the simulated gastric fluid $(0.1 \mathrm{~N} \mathrm{HCl}, \mathrm{pH} 1.2)$ in a $15 \mathrm{ml}$ test tube maintained at $37^{\circ} \mathrm{C}$ followed by the addition of $1 \mathrm{ml}$ of the formulation using a pipette. The pipette was positioned facing the surface of the fluid in the test tube and slowly the formulation was released from the pipette. When the formulation came in contact with the gelation medium, it was quickly converted into a gel-like structure. Based on the stiffness of gel as well as the duration, for which the gel remains as such the in vitro gelling capacity was investigated [10].

The in vitro gelling capacity was mainly divided into three categories based on gelation time and time period the formed gel remains.

- (+): Gels in few second and disperse immediately

- $(++)$ : Immediate gelation does not disperse rapidly

- $(+++)$ : Gelation after few minutes remains for extended periods.

\section{Determination of viscosity}

Viscosities of the formulations are determined with the help of Brookfield's digital Viscometer (DV-II) +Pro using S21 spindle at $50 \mathrm{rpm}$ and measurement was for done for 6 times with fresh samples being used each time and the average reading was taken.

\section{In vitro buoyancy study}

The studies were conducted in a USP Type II dissolution apparatus using simulated gastric fluid $(0.1 \mathrm{~N} \mathrm{HCl}, \mathrm{pH})$ as the dissolution medium at $37 \pm 0.5^{\circ} \mathrm{C}$. About $10 \mathrm{ml}$ of the in situ gel formulation was placed in the dissolution medium. The time taken by the in situ gel formulation on the surface of the medium (floating lag time) and time period for which the formulation remained buoyant (duration of floating) was noted [11].

\section{Determination of the drug content}

$5 \mathrm{ml}$ of the formulation equivalent to $10 \mathrm{mg}$ of the drug was added to $80 \mathrm{ml}$ of $0.1 \mathrm{~N} \mathrm{HCl}, \mathrm{pH} 1.2$, and stirred for $1 \mathrm{~h}$ in a magnetic stirrer. After
$1 \mathrm{~h}$, the solution was filtered and diluted with $0.1 \mathrm{~N} \mathrm{HCl}, \mathrm{pH} 1.2$. The drug concentration was then determined by ultraviolet (UV) visible spectrophotometer at $279 \mathrm{~nm}$ against a suitable blank solution [12].

\section{Measurement of water uptake by the gel}

To conduct this study, the in situ gel formed in $40 \mathrm{ml}$ of $0.1 \mathrm{~N} \mathrm{HCl}, \mathrm{pH} 1.2$ has been used. From each of the formulation, the gel part was separated from the buffer and the excess buffer was blotted out with the help of Whatman filter paper. The gel was initially weighed and its weight was noted, followed by the addition of $10 \mathrm{ml}$ distilled water to this gel. After every 30 min interval, water was decanted and weight of the gel was noted and difference between initial and final weight was calculated and recorded [13].

\section{Measurement of density of gel}

$30 \mathrm{ml}$ of the in situ formulation was poured into a beaker containing $50 \mathrm{ml}$ of $0.1 \mathrm{~N} \mathrm{HCl} .10 \mathrm{ml}$ of the gel formed was taken in measuring cylinder and weight of the gel was measured. Using the weight as well as the volume of the gel, the density was calculated. This method was followed for all the formulations [14].

\section{Measurement of gel strength}

$30 \mathrm{~g}$ of the gel was taken in a $50 \mathrm{ml}$ beaker and a $50 \mathrm{~g}$ weight was placed on the center of the surface of the gel and allowed to penetrate through the gel. The time taken by the $50 \mathrm{~g}$ weight to penetrate $5 \mathrm{~cm}$ down through the gel was noted for all the formulations. The same method was followed for 6 times for each fresh formulation and average time was noted [15].

\section{In vitro drug release study of the in situ gel formulation}

The drug release of the formulations was determined using a USP dissolution apparatus (Type II) with a paddle stirrer at $50 \mathrm{rpm}$. This slow speed is necessary to avoid breaking of the gelled formulation. $500 \mathrm{ml}$ of the simulated gastric fluid $(0.1 \mathrm{~N} \mathrm{HCl}, \mathrm{pH} 1.2)$ was used as the dissolution medium and the temperature was maintained at $37 \pm 0.5^{\circ} \mathrm{C} .10 \mathrm{ml}$ of the formulation was introduced into the dissolution vessel without disturbing the dissolution medium resulting in the formation of in situ gel. At each time interval, $3 \mathrm{ml}$ of the sample was withdrawn and replenished with fresh medium. The samples collected were filtered, suitably diluted, and analyzed at $279 \mathrm{~nm}$ using UV spectrophotometer [16].

\section{Drug release kinetics study [17]}

To study drug release kinetics of in situ gel formulation, data obtained from in vitro drug release studies were plotted in various kinetic models: Zero order (Equation: 1) as

cumulative percentage of drug released versus time, first order (Equation: 2) as log cumulative percentage of drug remaining versus time

Zero-order equation $\mathrm{Q}_{\mathrm{t}}=\mathrm{Q}_{0}+\mathrm{K}_{0} \mathrm{t}$

First-order equation $\log \mathrm{Q}=\log \mathrm{Q}_{0}-\mathrm{K}_{1} \mathrm{t} / 2.303$

where $Q_{t}$ is the percentage of drug release at time $t$ and $K_{0}$ and $K_{1}$ are the coefficients of the equation.

\section{Mechanism of drug release}

Mechanism of drug release from drug-loaded SLN was evaluated by subjecting the data obtained from in vitro drug diffusion studies in Higuchi's model (Equation: 3) as cumulative percentage of drug released versus square root of time and Korsmeyer-Peppa's model (Equation: 4) as log cumulative percentage drug released versus log time.

Higuchi equation, $\mathrm{Q}=\mathrm{Kt}_{1 / 2}$

Korsmeyer-Peppas model equation, $\mathrm{Mt} / \mathrm{M} \infty=\mathrm{Kt}^{\mathrm{n}}$ 
where $\mathrm{Mt} / \mathrm{M} \infty$ is a fraction of drug released at time $\mathrm{t}, \mathrm{K}$ is the release rate constant, and $\mathrm{n}$ is the release exponent.

\section{In vivo fluorescence imaging}

Health mice of either sex were divided into two groups of three mice each. One group received the optimized formulation and another group was given a conventional non-gel solution and will be served as the control. Mice were fasted for $24 \mathrm{~h}$ before administration of the formulations but were allowed free access to water. 0.2-0.4 ml of the optimized formulation containing the appropriate amount of sodium fluorescein calculated based on the body weight was orally administered to the mice and fluorescence images were recorded at $535 \mathrm{~nm}$ at $1 \mathrm{~h}$ time intervals for $6-8 \mathrm{~h} \mathrm{[18]}$.

\section{Stability studies}

The optimized formulation of in situ gel was placed in an amber color bottle with aluminum cap as a closure. It was tightly sealed. The stability study was carried out as per the ICH guideline, i.e., $5^{\circ} \mathrm{C} \pm 3^{\circ} \mathrm{C}$ (refrigerator), room temperature of $25^{\circ} \mathrm{C} \pm 2^{\circ} \mathrm{C} / 60 \% \pm 5 \% \mathrm{RH}$, and accelerated temperature $40 \pm 2^{\circ} \mathrm{C} / 75 \% \pm 5 \%$ RH for 1 month. Samples were withdrawn periodically $(0,15$, and 50 days $)$ and evaluated for visual appearance, drug content, $\mathrm{pH}$ as well as floating behavior [19].

\section{RESULT AND DISCUSSION}

FTIR and compatibility studies

No considerable changes in the IR peaks of the drug were observed in the optimized formulation when compared with pure drug as shown in Table 2, which indicate the absence of any chemical incompatibility between drug and excipients.

\section{Characterization of the in situ gel formulations \\ Visual appearance}

The visual appeal of the formulation is an important parameter as it has an impact on the patient compliance. All the formulations were subjected to visual appearance. The results are given in Table 3 and all the prepared formulations had off-white appearance. The formulations were free running and did not produce any gelation at room temperature.

\section{pH measurements}

The $\mathrm{pH}$ of all the formulation was found to be satisfactory in the range of 6.72-7.25 as depicted in Table 3. The $\mathrm{pH}$ of all the formulations was within the orally acceptable range. Therefore, it will not cause any irritation on administration of the formulations.

\section{In vitro gelation study}

The gelation study was conducted in $0.1 \mathrm{~N} \mathrm{HCl}, \mathrm{pH} \quad 1.2$. Gelation characteristics of the formulations were assessed on an ordinal scale ranging between + and +++ as shown in Table 3 . All the formulations on contact with the gelation medium had undergone sol-to-gel transition. In the presence of gel-forming polymers such as sodium alginate and gellan gum and also calcium carbonate and trisodium citrate. The in situ released calcium ion from calcium citrate complex gets entrapped in polymeric chains resulting in the cross-linking of polymer chains to form a gel matrix. Thus, stiff gels were formed with formulations containing high concentrations of sodium alginate, formulations containing combination of sodium alginate and gellan gum as well as sodium alginate along with xanthum gum.

Viscosity

The viscosity of all the in situ gelling formulations determined at $50 \mathrm{rpm}$ at $25^{\circ} \mathrm{C}$ using Brookfield DV-II+Pro. The results of viscosity measurement of all the formulations are shown in Table 5. The order of viscosity of the formulations from F1 to F9 is F9 $>$ F8 $>$ F7 $>$ F6 $>$ F5 $>$ F4 $>$ F3 $>$ F2 $>$ F1. The increase in viscosity of the formulations that were observed with the increase in the concentration of polymer can be related to the increasing crosslinking of the polymer. Formulations containing xanthum gum have higher viscosities because of the viscosity enhancement property of xanthum gum. Formulations F8 and F9 were too viscous, making them difficult to pour from the container.

\section{In vitro buoyancy study}

The time taken by the formulation to emerge on the surface of the medium is the floating lag time and the time period for which the formulation constantly floated on the surface of the medium is known as floating duration. Buoyancy studies results are given in Table 4 . When the formulation comes in contact with the acidic environment, gelation as well as cross-linking of the calcium ions takes place providing a gel barrier on the surface of formulation. The carbon dioxide released is entrapped in the gel matrix giving buoyancy to the formulation. Then the polymeric network further restricts the diffusion of carbon dioxide as well as drug release. The floating ability of the formulations mainly depends on concentration of the gelling polymer, carbon dioxide, and cation source. All the in situ gel formulations had a floating lag time of

Table 1: Composition of the in situ gelling formulations

\begin{tabular}{|c|c|c|c|c|c|c|c|c|c|}
\hline \multirow[t]{2}{*}{ Ingredients } & \multicolumn{9}{|c|}{ Formulation code } \\
\hline & F1 & F2 & F3 & F4 & F5 & F6 & F7 & F8 & F9 \\
\hline Lafutidine $(10 \mathrm{mg} / 5 \mathrm{ml})$ & 200 & 200 & 200 & 200 & 200 & 200 & 200 & 200 & 200 \\
\hline Gellan gum & & & & 0.75 & 0.75 & 0.75 & & & \\
\hline Xanthum gum & & & & & & & 0.25 & 0.25 & 0.25 \\
\hline Trisodium citrate & 0.2 & 0.2 & 0.2 & 0.2 & 0.2 & 0.2 & 0.2 & 0.2 & 0.2 \\
\hline Calcium carbonate & 1 & 1 & 1 & 1 & 1 & 1 & 1 & 1 & 1 \\
\hline Tween 80 & 2.5 & 2.5 & 2.5 & 2.5 & 2.5 & 2.5 & 2.5 & 2.5 & 2.5 \\
\hline Liquid paraffin & 2.5 & 2.5 & 2.5 & 2.5 & 2.5 & 2.5 & 2.5 & 2.5 & 2.5 \\
\hline Propylparaben & 0.09 & 0.09 & 0.09 & 0.09 & 0.09 & 0.09 & 0.09 & 0.09 & 0.09 \\
\hline Methylparaben & 0.01 & 0.01 & 0.01 & 0.01 & 0.01 & 0.01 & 0.01 & 0.01 & 0.01 \\
\hline
\end{tabular}

Table 2: Major IR peaks of lafutidine and optimized formulation

\begin{tabular}{lll}
\hline Samples & Composition & Major peak (wave numbers $\mathbf{~ c m}^{-1}$ ) \\
\hline A & Pure lafutidine & $3282.84,2933.73,2791.00,2752.42,2357.01,2791.00,2752.42,2357.01,1654.92,1608.63,1550.77$, \\
& & 1346.31 \\
B & Optimized formulation (F9) & $3282.14,2933.73,2791.00,2752.42,2357.01,1753.29,1656.85,1608.63,1546.91,1477.47,1398.39$, \\
& & 1301.95 \\
\hline
\end{tabular}

IR: Infrared 
$<2 \mathrm{~min}$ and all the formulations floated for more than $12 \mathrm{~h}$. Therefore, the extended duration of floating was responsible for the sustained release of drug.

\section{Drug content}

Drug content is one of the important evaluation parameters for any type of dosage form. The percentage drug content of all the formulations was in the range of 88.74-95.90 indicating uniform distribution of drugs in all formulations as per monograph.

\section{Water uptake by the gel}

The amount of water associated with the drug delivery system plays an important role in determining the release of the drug from the polymer matrix. The drug release mainly involves the penetration of water into

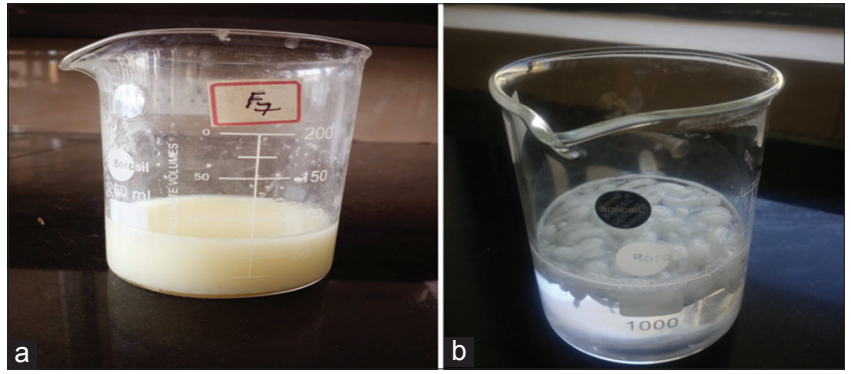

Fig. 1: (a) In situ gelling formulation of lafutidine (b) gastroretentive in situ gel of lafutidine

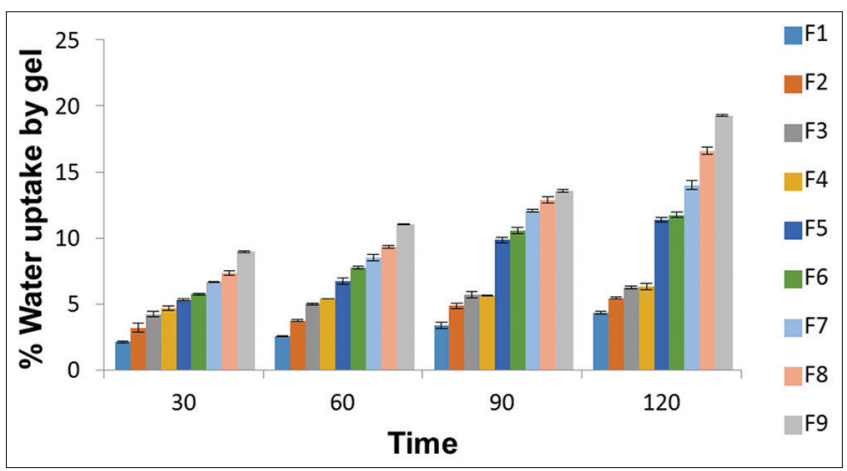

Fig. 2: Histogram of water uptake of in situ gel formulations at different time interval

Table 3: Appearance, $\mathrm{pH}$ and gelling capacity, and pourability of the in situ gel formulations

\begin{tabular}{|c|c|c|c|c|}
\hline $\begin{array}{l}\text { Formulation } \\
\text { code }\end{array}$ & Appearance & pH & $\begin{array}{l}\text { Gelling } \\
\text { capacity }\end{array}$ & Pourability \\
\hline F1 & Off-white & $6.72 \pm 0.06$ & +++ & $\begin{array}{l}\text { Easily } \\
\text { pourable }\end{array}$ \\
\hline F2 & Off-white & $7.25 \pm 0.09$ & +++ & $\begin{array}{l}\text { Easily } \\
\text { pourable }\end{array}$ \\
\hline F3 & Off-white & $6.78 \pm 0.04$ & +++ & $\begin{array}{l}\text { Easily } \\
\text { pourable }\end{array}$ \\
\hline $\mathrm{F} 4$ & Off-white & $6.83 \pm 0.02$ & +++ & $\begin{array}{l}\text { Easily } \\
\text { pourable }\end{array}$ \\
\hline F5 & Off-white & $6.88 \pm 0.07$ & +++ & $\begin{array}{l}\text { Easily } \\
\text { pourable }\end{array}$ \\
\hline F6 & Off-white & $6.73 \pm 0.04$ & +++ & $\begin{array}{l}\text { Easily } \\
\text { pourable }\end{array}$ \\
\hline F7 & Off-white & $6.96 \pm 0.05$ & +++ & $\begin{array}{l}\text { Easily } \\
\text { Pourable }\end{array}$ \\
\hline F8 & Off-white & $7.20 \pm 0.03$ & +++ & Pourable \\
\hline F9 & Off-white & $7.14 \pm 0.07$ & +++ & Pourable \\
\hline
\end{tabular}

the matrix and simultaneous release of the drug through diffusion or dissolution. The percentage water uptake of all the formulations is given in Fig. 3. When compared with other formulations, F9 showed a better water uptake of $19.26 \%$. The high water uptake may be because of the high swelling capacity of the polymer as the concentration of the polymer increases the water uptake by the gel also increases.

\section{Measurement of density of the gel}

Density is an important evaluation parameter as far as the buoyancy ability of the gastroretentive dosage form is concerned. For the formulation to float on the gastric contents, it should have a density less than or equal to that of the gastric contents $\left(\sim 1.004 \mathrm{gcm}^{-3}\right)$. The density of all the formulations given in Table 5 has density less than the abovespecified value. As a result, the floating of the gastroretentive in situ gel is promoted in the stomach.

\section{Measurement of gel strength}

All the formulations showed good gel strength which ranged from as low as $15.3 \mathrm{~s}$ for F1 to higher values of 65.6 for F9 formulations which have the combination of sodium alginate and gellan gum. Gel strength gives an indication about the tensile strength of the gelled mass. It demonstrates the ability of the gelled mass to withstand the peristaltic movement in in vivo. Table 5 gives the gel strength of all the formulations.

\section{In vitro drug release study of the in situ gel formulation}

The in vitro drug release studies, it was observed that as the concentration of gelling agent increase, release of drug from the gastroretentive in situ gel prepared decreases. Drug releasing pattern of different formulation contains a different concentration of gelling agent and drug release retardant polymers are given as follows: With sodium alginate: $\mathrm{F} 1>\mathrm{F} 2>\mathrm{F} 3$, with sodium alginate and gellan gum: F4 $>$ F5 $>$ F6 and with sodium alginate and xanthum gum: F7 $>$ F8 $>$ F9 as shown in Figs. 4-6. The percentage drug release from formulations containing different concentrations of sodium alginate at the end of $12 \mathrm{~h}$ was found to be $82.76 \%, 78.90 \%$, and $76.24 \%$, respectively, for F1, F2, and F3.

Similarly, percentage drug release from formulations containing different concentrations of sodium alginate and gellan gum at the end of $12 \mathrm{~h}$ was found to be $77.23 \%, 75.23 \%$, and $71.47 \%$, respectively, for F4, F5, and F6. The retarded release observed in formulations F4, F5, and F6 is because the gelation and aggregation of gellan gum occur through chemical bonding between calcium and carboxylic groups in the gellan chains. Calcium, being a hard electrophile, interacts with the carboxylate group of gellan gum electrostatically.

The percentage drug release from formulations containing different concentrations of sodium alginate and constant amount of xanthum gum at the end of $12 \mathrm{~h}$ was found to be $58.23 \%, 55.24 \%$, and $51.84 \%$ respectively for F7, F8, and F9.

As the concentration of sodium alginate, sodium alginate with gellan gum, and sodium alginate with xanthum gum increased, there was a decrease in the drug release. In the formulations F7, F8, and F9, there was a drastic decrease in the drug release due to the presence of xanthum gum which acts as a drug release retardant polymer as well as viscosityenhancing agents. Xanthum gum hydrates rapidly without lumping and increases the viscosity. Even at low concentrations, xanthum gum imparts high viscosity. Due to high swelling nature of xanthum gum, it forms a thick gel structure which increased the diffusion path length of the drug as a result there is delayed release of the drug from the formulation. The result of this, the drug from formulation F7, F8, and F9 were shown sustained release pattern.

For kinetics study, release data of all in situ gel formulation were fitted to various kinetic models. All formulations followed first-order release kinetics with high linearity regression coefficient when compared to zero-order kinetic models. The mechanism of drug release from in situ 
Table 4: Viscosity, floating lag time, floating duration, and percentage drug content of the in situ gel formulation

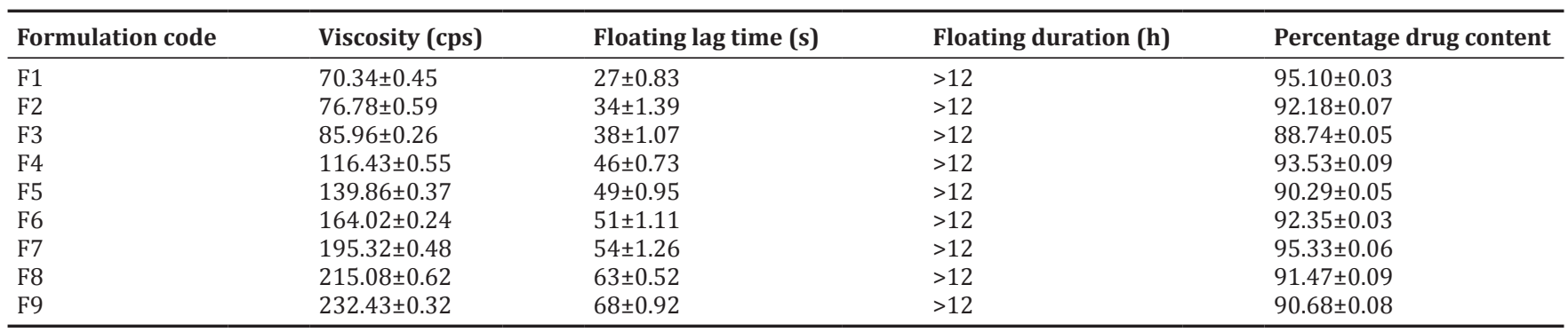

Table 5: Density and gel strength of the in situ gel formulation

\begin{tabular}{lll}
\hline Formulation code & Density $\left(\mathrm{g} \mathrm{cm}^{3}\right)$ & Gel strength $(\mathbf{s})$ \\
\hline F1 & $0.431 \pm 0.14$ & $15.3 \pm 0.13$ \\
F2 & $0.456 \pm 0.09$ & $19.7 \pm 0.15$ \\
F3 & $0.492 \pm 0.17$ & $25.4 \pm 0.20$ \\
F4 & $0.517 \pm 0.18$ & $28.5 \pm 0.14$ \\
F5 & $0.540 \pm 0.11$ & $35.6 \pm 0.23$ \\
F6 & $0.553 \pm 0.15$ & $42.3 \pm 0.08$ \\
F7 & $0.589 \pm 0.07$ & $53.2 \pm 0.11$ \\
F8 & $0.610 \pm 0.09$ & $59.2 \pm 0.07$ \\
F9 & $0.624 \pm 0.15$ & $65.6 \pm 0.10$ \\
\hline
\end{tabular}

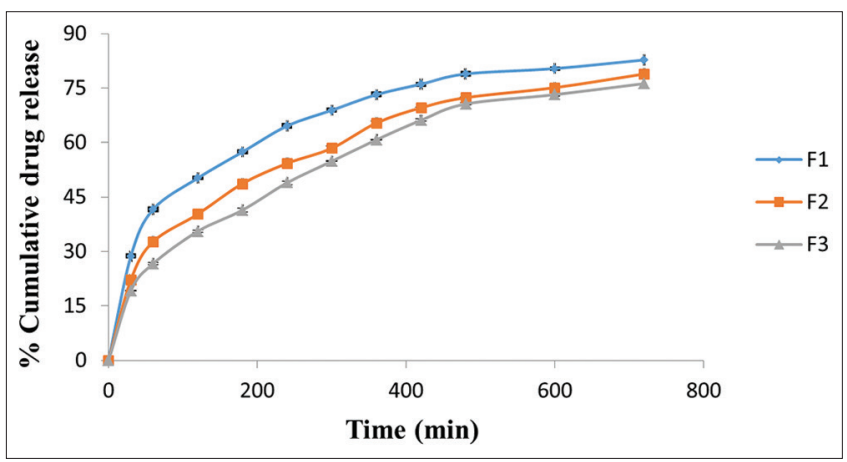

Fig. 3: Comparative in vitro drug release profile of formulations containing different concentrations of sodium alginate

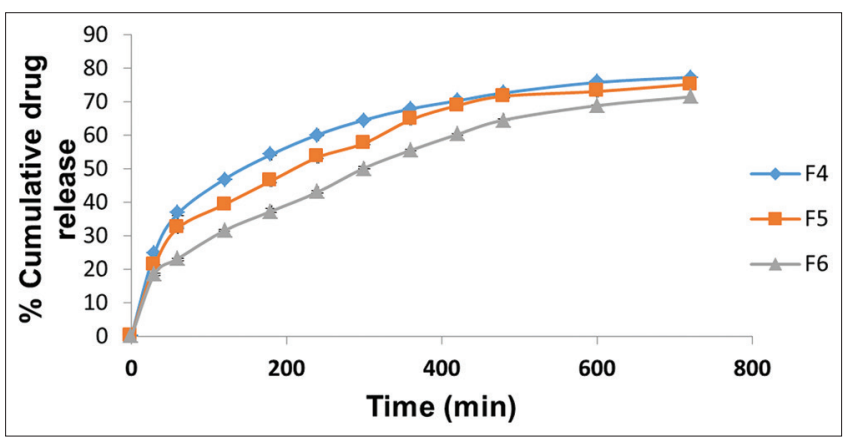

Fig. 4: Comparative in vitro drug release profile of formulations containing different concentrations of sodium alginate and gellan gum

gel formulation was studied by fitting the data into Higuchi's model and Korsmeyer-Peppas model. As per the drug release plot, Higuchi's model showed good linearity when compared with Korsmeyer-Peppas model, which shows that the drug release is governed by matrix diffusion process. It is dictated by the fact that gelling agent present in this swell upon imbibitions of water-created gelled matrix through which drug must diffuse.

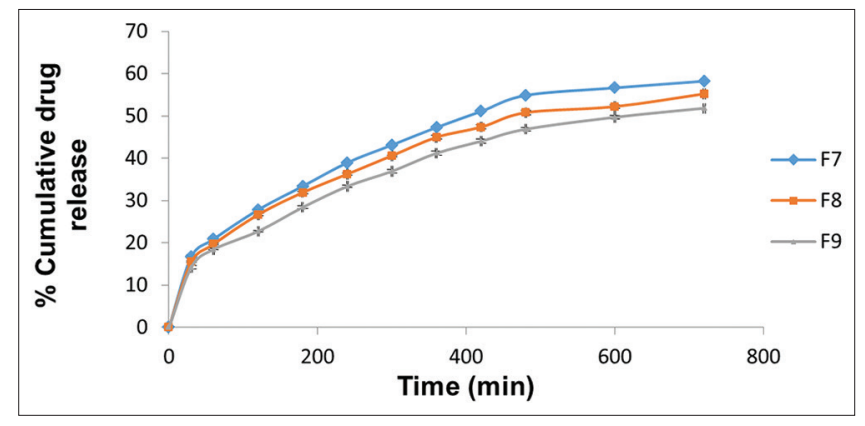

Fig. 5: In vitro drug release profile of in situ gel formulations containing different concentrations of sodium alginate and xanthum gum

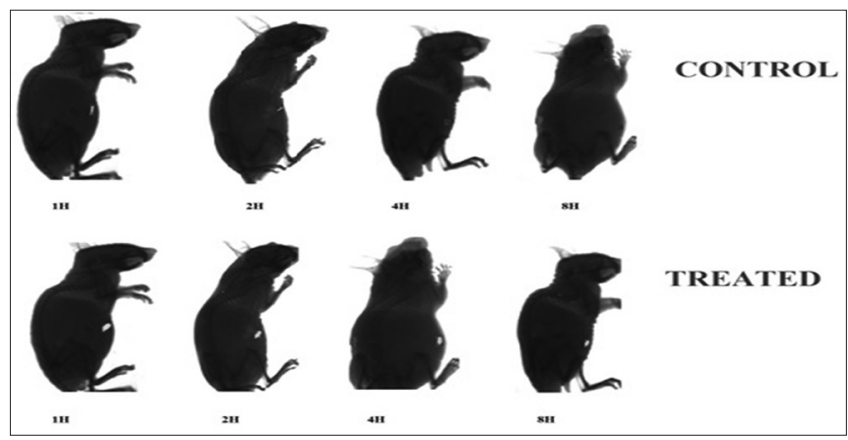

Fig. 6: In vivo fluorescence image of the control and gastroretentive in situ gel formulation

On the basis of all, the evaluated parameters of in situ gelling formulation and F7 were selected as the optimized formulation. Its easy pourability and viscosity, near to neutral $\mathrm{pH}$, gel strength and sustained drug release. All other formulations displayed incompetency in one or more of the above parameters.

In vivo fluorescence imaging

In vivo studies in mice were carried out by orally administering optimized formulation containing sodium fluorescein and comparing with the control by taking fluorescence images of control as well as optimized formulation at predetermined time intervals. From the fluorescence image of the optimized formulation (F7) obtained, it was observed that the formulation remained in the mice stomach for more than $8 \mathrm{~h}$. Thus, the successful gastroretention of the in situ gel formulation was demonstrated in the study.

\section{Stability studies}

The optimized formulation F7 was subjected for stability studies as per the ICH guidelines for 1 month. Stability study's results indicated that the there was no significant change in the visual appearance, floating behavior, and drug content as shown in Table 7. 
Table 6: Kinetic parameter for in vitro drug release of in situ gel formulations

\begin{tabular}{|c|c|c|c|c|c|c|c|c|c|}
\hline Kinetic model & F1 & F2 & F3 & F4 & F5 & F6 & F7 & F8 & F9 \\
\hline \multicolumn{10}{|l|}{ Zero order } \\
\hline $\mathrm{R}^{2}$ & 0.9217 & 0.96 & 0.9007 & 0.9627 & 0.102 & 0.9748 & 0.9747 & 0.9844 & 0.955 \\
\hline $\mathrm{K}$ & 0.1025 & 0.1062 & 0.0975 & 0.1065 & 0.991 & 0.0803 & 0.0764 & 0.0723 & 0.1008 \\
\hline \multicolumn{10}{|l|}{ First order } \\
\hline $\mathrm{R}^{2}$ & 0.9863 & 0.9941 & 0.9669 & 0.9938 & 0.9985 & 0.9929 & 0.992 & 0.9958 & 0.9998 \\
\hline K & 0.0011 & 0.001 & 0.0009 & 0.001 & 0.0008 & 0.0006 & 0.0005 & 0.0005 & 0.0008 \\
\hline \multicolumn{10}{|l|}{ Higuchi } \\
\hline $\mathrm{K}$ & 2.7324 & 2.8631 & 2.6398 & 2.8326 & 2.7985 & 2.1785 & 2.0592 & 1.9723 & 2.8226 \\
\hline \multicolumn{10}{|c|}{ Korsmeyer-Peppas Model } \\
\hline $\mathrm{R}^{2}$ & 0.9647 & 0.9573 & 0.9622 & 0.9829 & 0.9911 & 0.9938 & 0.9925 & 0.9916 & 0.9972 \\
\hline $\mathrm{K}$ & 0.3411 & 0.0294 & 0.3647 & 0.4158 & 0.4591 & 0.4248 & 0.4282 & 0.4369 & 0.4454 \\
\hline $\mathrm{N}$ & 0.8859 & 0.7546 & 0.8956 & 0.7352 & 0.5615 & 0.5771 & 0.5442 & 0.4864 & 0.6276 \\
\hline
\end{tabular}

Table 7: Results of stability studies of the in situ gel formulation

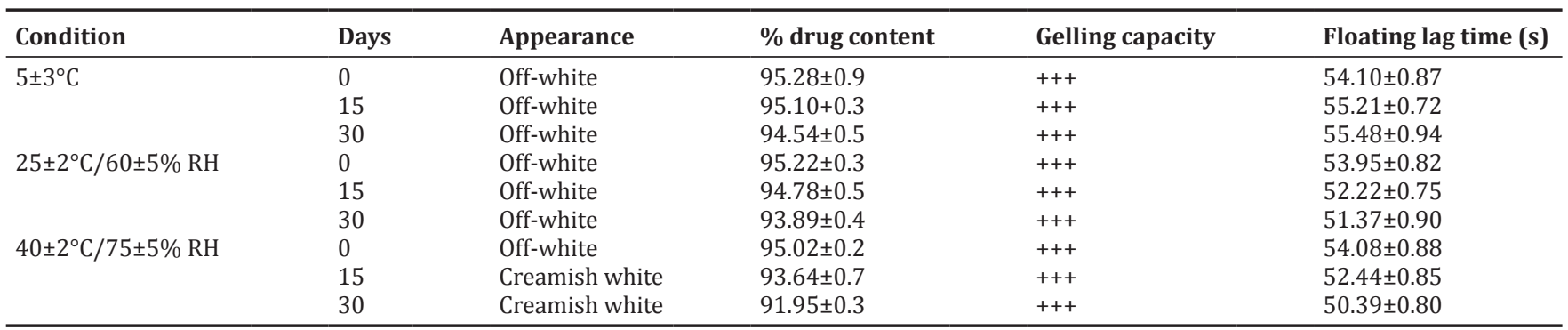

\section{CONCLUSION}

The present study has been a successful attempt to formulate gastroretentive in situ gel of lafutidine, an orally administrated antiulcer drug with a view to improving its oral bioavailability and provide sustained release of the drug. The developed formulations met all prerequisites to become gastroretentive in situ gel system that gelled and floated instantaneously in the $\mathrm{pH}$ conditions of the stomach. Hence, it can be concluded that stomach specific in situ forming gel of lafutidine can be an effective formulation that shows improved efficacy, prolonged release, patient compliance, and cost-effective over conventional formulation.

\section{ACKNOWLEDGMENTS}

The authors are thankful to Himalayan parenteral and formulations Pvt., Ltd., and Zuventus Healthcare for providing the gift samples of lafutidine. The authors are also thankful to Nitte Gulabi Shetty Memorial Institute of Pharmaceutical Sciences, Mangalore, for providing the necessary facilities to carry out the research work.

\section{AUTHORS CONTRIBUTION}

Sindhoor S M performed all formulation and characterizations of the studies. Amala Maxwell help him in various laboratory procedures. Dr. SnehPriya guided and supervised the study.

\section{CONFLICT OF INTERESTS}

The authors report no conflicts of interest. The authors alone are responsible for the content and writing of the paper.

\section{REFERENCES}

1. Madan JR, Adokar BR, Dua K. Development and evaluation of in situ gel of pregabalin. Int J Pharm Investig 2015;5:226-33.

2. Rohith G, Bhimagoni KS, Anegundha S. Floating drug delivery of a locally acting $\mathrm{H}_{2}$ antagonist: An approach using an in situ gelling liquid formulation. Acta Pharm 2009;59:345-54.

3. Shah J, Shah S, Upadhyay P, Parikh D. In situ gel: A novel approach of gastroretentive drug delivery. Asian J Biomed Pharm Sci 2012;2:1-8.

4. Thomas LM. Formulation and evaluation of floating oral in-situ gel of metronidazole. Int J Pharm Pharm Sci 2014;6:265-9.

5. Hasan MJ, Kamal BA. Formulation and evaluation of ranitidine hydrochlorideas floating in situ gel. Int J Pharm Pharm Sci 2014;6:401-5.

6. Swathi G, Lakshmi PK. Design and optimization of hydrodynamically balanced oral in situ gel of glipizide. J Appl Pharm Sci 2015;5:31-8.

7. Satish HP, Gokul ST. Formulation development and in vitro and in vivo evaluation of gastroretentive floating drug delivery system of lafutidine. Asian J Pharm 2013;7:68-74.

8. Sharma YR. Elementary Organic Spectroscopy. $4^{\text {th }}$ ed. New Delhi: S. Chand; 2007.

9. Parthiban S, Shivaraju, Senthilkumar GP, Vikneswari A. Formulation and evaluation of gastroretentive drug delivery of ornidazole in situ gellingsystem using gellan gum. Int $\mathrm{J}$ Res Pharm Nano Sci 2013;2:747-56.

10. Jayswal BD, Yadav VT, Patel KN, Patel BA, Patel PA. Formulation and evaluation of floating in situ gel based gastro retentive drug delivery of cimetidine. Int J Pharm Res Scholars 2012;1:327-37.

11. Patel RP, Ladani R, Dadhaniya B, Prajapathi BG. In situ gel delivery systems for chlordiazepoxide using artificial neural network. Int $\mathrm{J}$ Pharm Health Sci 2015;1:10-22.

12. Pandya K, Agarwal P, Dashora A, Sahu D, Garg R, Pareta KL, et al. Formulation and evaluation of oral floatable in situ gel of ranitidine hydrochloride. J Drug Del Ther 2013;3:90-7.

13. Parekh KS, Shah KV. Formulation development and evaluation of oral in situ floating gel of domperidone. Int J Pharm Sci 2013;4:228-46.

14. Gulecha BS, Shahi S, Lahoti SR. Floating in situ gelling drug delivery system of verapamil hydrochloride. Am J Pharm Tech Res 2012;2:955-69.

15. Wamorkar V, Varma MM, Manjunath SY. Formulation and evaluation of Stomach specific in situ gel of metaclopramide using natural, biodegradable polymers. Int J Res Pharm Biomed Sci 2011;2:193-201.

16. Singhvi G, Singh M. Review: In vitro drug release characterization models. Int Pharm Sci Res 2011;2:77-84.

17. Dash A, Murthy PN, Nath L, Chowdhury P. Kinetic modeling on drug release from controlled drug delivery systems. Acta Poloniae Pharm Drug Res 2010;67:217-23.

18. Teng L, Wang D, Zhao J, Liu X, Sun F, Zhou L, et al. Parenteral thermo-sensitive organogel for schizophrenia therapy. Eur J Pharm Sci 2014;60:40-8

19. WHO-GMP and ICH Stability Testing Guidelines for Drug Products. The Pharmaceutical Sciences-Pharma Pathway; 2.72-2.79. 
